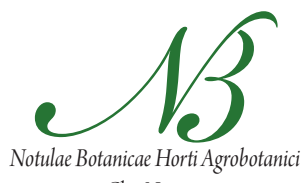

Cluj-Napoca

\title{
The Mineral Source for Human Nutrition of Nuts in Different Hazelnut (Corylus avellana L.) Cultivars
}

\author{
Sina COSMULESCU ${ }^{*}$, Mihai BOTU ${ }^{1}$, Ion TRANDAFIR² \\ ${ }^{1}$ University of Craiova, Agriculture and Horticulture Faculty, Department of Horticulture and Food Science, A.I.Cuza \\ Street, 13, 200585, Craiova, Romania; sinacosmulescu@hotmail.com (*correspondingauthor) \\ ${ }^{2}$ University of Craiova, Sciences Faculty, Department of Chemistry, Calea Bucuresti Street, 107, 200529, Craiova, Romania
}

\begin{abstract}
Hazelnuts (Corylus avellana L.) have a significant place among the types of dried nuts in terms of nutrition and health owing to their special composition of fats, protein, carbohydrates, vitamins, minerals, dietary fibers and phenolic antioxidants. Different hazelnut cultivars grown in Romania ('Cozia,' 'Romavel', 'Valcea 22', 'Roverd' and 'Red Lambert') were evaluated for their mineral composition. Microelements were determined by using ICP-MS and a Flame AAS. The average microelements concentrations in the cultivars have varied in the following ranges $\left(\mathrm{mg} 100 \mathrm{~g}^{-1}\right): \mathrm{K}, 591.75$ - 639.13; P, 300.67 - 455.06; Mg, 205.02 - 335.54; Ca, 72.07 - $130.92 ; \mathrm{Mn}, 8.77$ 19.07; Fe, 5.3 - 8.77; Cu, 1.62 - 3.07; Zn, 1.82 - 2.84; Cr, 0.12 - 0.84; Na, 0.36 - 0.97; Al, 0.23 - 0.35; Sr, 0.88 - 1.6; Rb,1.34 - 3.03. According to the daily microelement requirements, the quantity of $100 \mathrm{~g}$ hazelnut provided approximately $13 \%$ for $\mathrm{K}, 55 \% \mathrm{for} \mathrm{P}, 70 \% \mathrm{for} \mathrm{Mg}$, $10 \%$ for $\mathrm{Ca}, 94 \%$ for $\mathrm{Fe}, 22$ for $\mathrm{Zn}$ and $5.6 \%$ for $\mathrm{Cr}$ of the RDA. These results indicated that hazelnuts are a rich source of a number of important micro-elements and hazelnut can be an important source of microelements for human nutrition and health.
\end{abstract}

Keywords: Corylus avellana, healthy, nutritional composition, recommended daily amount

\section{Introduction}

Minerals are essential in maintaining the healthy nerve function and for keeping the body systems, bones and cells healthy and well balanced. There are foods that contain the necessary minerals which our bodies absolutely need. Fruits and vegetables are therefore getting broader attention in a strategy to increase the nutritional value of meals while reducing energy density and intake (Demigné et al., 2004). Hazelnuts (Corylus avellana L.) have a significant place among the types of dried nuts in terms of nutrition and health owing to their special composition of fats, protein, carbohydrates, vitamins, minerals, dietary fibers and phenolic antioxidants (Demirbas, 2007; Simsek and Aykut, 2007; Solar and Stampar, 2011). The nutritional and sensory properties of hazelnuts make them a unique and ideal raw material for food products. Hazelnut fruits are different in morphologic characteristics and mineral composition with an extremely high variability among genotypes of different origins (Ferreira et al., 2010; Rovira et al., 2005). They are a rich source of main nutritive matter that seem to have positive effect on human health (Cristofori et al., 2008; Oliveira et al., 2008; Schmitzer et al., 2011; Silva et al., 2007). Regarding mineral composition, Alasalvar et al. (2003) considered that the major minerals in hazelnut were potassium, phosphorus, calcium, magnesium, and selenium. Iron, copper, manganese and zinc content were reported by Dundar et al. (2002) in hulled kernels, which is $3.45,1.61,12.72,2.63 \mathrm{mg} / 100 \mathrm{~g}$, respectively. Hazelnut cultivars served as an excellent source of copper and manganese. Alasalvar et al. (2009) suggested that the consumption of the recommended daily amount of $42.5 \mathrm{~g}$ of hazelnut from different cultivars provides $44.4-83.6 \%$ of copper and $40.1-448 \%$ of recommended manganese intake for adults. According to the daily microelement requirements, $100 \mathrm{~g}$ of Turkish hazelnut cultivars has supplied about $50 \%$ for $\mathrm{Fe}$ and $\mathrm{Cd}, 41 \%$ for Mo, 32\% for Zn, $21 \%$ for Se, $21 \%$ for Cr, $5 \%$ for B, $1 \%$ for $\mathrm{Ni}$ of the recommended daily amount (Özkutlu et al., 2011). Hazelnut is the best source of essential elements, amino acids, vitamin B and $\mathrm{E}$ among tree nuts (Açkurt et al., 1999; Oliveira et al., 2008; Xu and Hanna, 2011) and serves as a good source of natural antioxidants (Açkurt et al., 1999; Contini et al., 2008; Schmitzer et al., 2011). Several studies indicated that the nut composition of hazelnut is affected by cultivar, harvest year, soil and geographical origin (Açkurt et al., 1999; Amaral et al., 2006; Dundar et al., 2002; Seyhan et al., 2007).

The present study is focused on the mineral content of four Romanian hazelnut cultivars ('Cozia', 'Romavel', 'Valcea 22', and 'Roverd') and one foreign one ('Red Lambert'), analyzed in mineralized samples with a previously validated method under optimized conditions for each element. The study has also evaluated the contribution of hazelnut to the total dietary intake of $\mathrm{Na}, \mathrm{K}, \mathrm{Ca}, \mathrm{Mg}, \mathrm{Fe}$, $\mathrm{Mn}, \mathrm{Cu}, \mathrm{Al}, \mathrm{Cr}, \mathrm{Zn}, \mathrm{Sr}, \mathrm{Rb}$, and $\mathrm{P}$. The growing consump- 
tion of nuts on the basis of its nutritional properties and beneficial effects requires a periodical control of the mineral presence.

\section{Materials and methods}

\section{Material}

The study was conducted by using five hazelnut (Corylus avellana L.) cultivars 4 Romanian bred cultivars ('Cozia,, 'Romavel', 'Valcea 22', and 'Roverd') and one foreign one ('Red Lambert') for determinations. The Romanian cultivars are the results of the breeding program for hazelnut from the Valcea Research Station (Botu et al., 2005). The material of study (fruit) comes from the germplasm collection of Valcea Research Station, located in SubCarpathian area in Oltenia Region, Romania (45.6'17' $\mathrm{N}, 24^{\circ} 22^{\prime} 32^{\prime \prime} \mathrm{E}$ ). The area has a temperate climate and is known to be favorable for hazelnut culture. Samples were taken from germplasm collection, 10 plant samples (100 $\mathrm{g}$ fruit per tree) for each cultivar were collected randomly at the beginning of the harvest season (2011). Hazelnut samples were packed into polyethylene bags, stored as inshell at room temperature conditions for two weeks and were cracked by using mechanical crackers. Kernels were homogenized in a blender.

\section{Mineral analysis}

A commercial system of Inductively coupled plasma mass spectrometry (ICP-MS; Perkin-Elmer Elan 9000), a Flame atomic absorption spectrometer (Flame AAS; Avanta PM) and a Milestone digestion microwave system were used. The experimental operating parameters are summarized in Tab. 1.

\section{Reagent and chemicals}

Etalon standards were obtained from multi-element stock solutions ICP-MS calibration STD 3, etalon solutions mono-element $1000 \mathrm{ppm} \mathrm{K}$, nitric acid 65\% puriss

Tab. 1. ICP-MS and the Atomic Absorption Spectrometer in flame operating conditions

\begin{tabular}{|cc|}
\hline \multicolumn{2}{|c|}{ ICP-MS, model Elan 9000} \\
\hline Rf power $(\mathrm{W})$ & 1000 \\
\hline ICP torch & Fassele type \\
\hline Torch injector & Ceramic alumina \\
\hline Nebulizer & Type cross flow \\
\hline Nebulizer gas flow $(\mathrm{l} / \mathrm{min})$ & 0.93 \\
\hline Spray chamber & 20 \\
\hline Sweeps $/$ reading & 2 \\
\hline Reading $/$ replicate & 5 \\
\hline Number of replicates & \\
\hline Flame AAS, model AvantaPM \\
\hline Optics & Double fascicle \\
Flame & Air-Acetylene \\
\hline Flame Control & Programmed \\
\hline
\end{tabular}

p.a (Fluka, Germany), oxygenated water 33\% reactive p.a and ultrapure water, of $1^{\text {st }}$ degree, according to ISO 3696:1987.

\section{Method}

For solid sample mineralization, a Milestone digestion microwave system was used. The amounts of approximately $0.5 \mathrm{~g}$ per sample, $6 \mathrm{ml}$ of $65 \%$ nitric acid and $2 \mathrm{ml}$ of $33 \%$ oxygenated water, were introduced in Teflon recipients, and were put under thermic treatment programme under pressure: heating them up to $180^{\circ} \mathrm{C}$ by a rate of $4.5^{\circ} \mathrm{C} / \mathrm{min}$ and keeping them for 20 minutes at $180^{\circ} \mathrm{C}$. After cooling down, the liquid samples were transferred into marked glass balloons; they were brought to $50 \mathrm{ml}$ volume, by using ultrapure water, and were analyzed according to specific procedures in the two spectrometer instruments. Control sample (blank) was made of $6 \mathrm{ml}$ nitric acid $65 \%$ and 2 $\mathrm{ml}$ oxygenated water $33 \%$; and it was processed under the same conditions as the analyzed sample. Mineral elements $\mathrm{P}, \mathrm{Mg}, \mathrm{Ca}, \mathrm{Mn}, \mathrm{Fe}, \mathrm{Zn}, \mathrm{Cu}, \mathrm{Rb}, \mathrm{Sr}, \mathrm{Na}, \mathrm{Cr}$ and $\mathrm{Al}$ (method 985.35, 999.10, 986.24) and $\mathrm{K}$ (method 985.35) were determined according to the official methods of the Association of Official Analytical Chemists (AOAC 2000). Three independent samples were performed for each determination and the resulting data were used to obtain average values and standard deviations for all tests. The method was previously described by Cosmulescu et al. (2010).

\section{Statistical analysis}

Results were expressed as means \pm standard deviation (SD). The statistical significance ( $t$-test) was determined using Minitab Statistical software. Differences at $p<0.05$ were considered to be significant.

\section{Results and discussion}

Hazelnuts are considered to be a good source of dietary minerals (Özkutlu et al., 2011). As they contains significant amounts of essential minerals that are associated with an improved health status when consumed at doses beyond those required for preventing a deficiency state (Alasalvar et al., 2009). The composition of mineral elements in five hazelnut cultivars was analyzed. Thirteen essential minerals were determined in the hazelnut cultivars and the results are given in Tab. 2 and Tab. 3 and the results indicated significant differences between the cultivars analyzed $(p$ $\leq 0.05)$. With regard to nutritional aspects, the percentage of RDA/AI for minerals need for human beings is given in Tab. 4. The order of nutritive elements depending on their content/100 g of produce was: $\mathrm{K}>\mathrm{P}>\mathrm{Mg}>\mathrm{Ca}>\mathrm{Mn}>$ $\mathrm{Fe}>\mathrm{Zn}>\mathrm{Cu}>\mathrm{Rb}>\mathrm{Sr}>\mathrm{Na}>\mathrm{Cr}>\mathrm{Al}$.

Among the identified elements, the highest amount was obtained in potassium, between $591.75 \mathrm{mg} 100 \mathrm{~g}^{-1}$ ('Red Lambert') and $639.13 \mathrm{mg} 100 \mathrm{~g}^{-1}$ ('Valcea 22'). Potassium concentrations in our study were lower than those reported by the Koksal et al. (2006) for Turkish varieties 
252

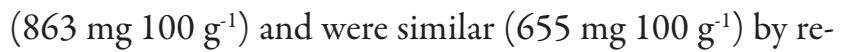
ported Alphan et al. (1997). Potassium is important for a healthy nervous system and a normal heart rate (Demigné et al., 2004). The recommended intake of potassium for all adult males and females is 4.7 grams per each day (Tab. 4); hazelnut is a good source of potassium. The consumption of $100 \mathrm{~g}$ hazelnut supplies about $13 \%$ of potassium intake (Tab. 2 and 3).

Phosphorus content ranged from $300.67 \mathrm{mg} 100 \mathrm{~g}^{-1}$

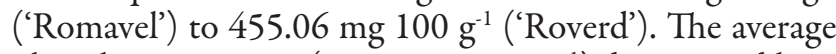

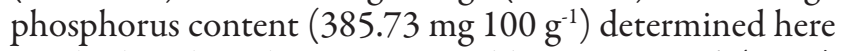
was higher than the one reported by Gunes et al. (2010) for the hazelnut cultivars grown in the West Black Sea Region of Turkey $\left(231.34 \mathrm{mg} 100 \mathrm{~g} \mathrm{~g}^{-1}\right)$. Phosphorus is a component of bones, cells, in energy processing and many other functions. The recommended intake of phosphorus is $700 \mathrm{mg}$ daily for both adult males and females (Tab. 4). According to the present study results, the consumption of $100 \mathrm{~g}$ hazelnut supplies about $55 \%$ of phosphorus intake (Tab. 2 and 3).

Tab. 2. Essential mineral ${ }^{a}$ content of hazelnut varieties
Magnesium plays an essential role in reducing the risk of cardio-vascular disease. Fruits analyzed have recorded a higher content of magnesium; the values were 205.02

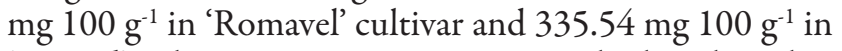
'Roverd' cultivar. Magnesium content is higher than that one found (173 mg $100 \mathrm{~g}^{-1}$ ) by Koksal et al. (2006) or the one found (1588 - $\left.1867 \mathrm{mg} \mathrm{kg}^{-1}\right)$ by Ozdemir and Akinci (2004) in cultivars grown in Turkey. The recommended intake for adult is $400 \mathrm{mg}$ daily; consuming RDA of $100 \mathrm{~g}$ hazelnut supplies $70 \%$ of magnesium.

Calcium content varied between $72.07 \mathrm{mg} 100 \mathrm{~g}^{-1}$

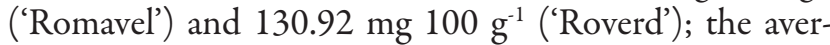

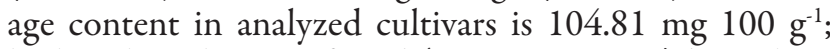
higher than that one found $\left(83.5 \mathrm{mg} 100 \mathrm{~g} \mathrm{~g}^{-1}\right)$ by Açkurt et al. (1999). The recommended amount of calcium for adults (ages 19-50), is $1000 \mathrm{mg}$ daily; consumption of 100 g hazelnut is supplying $10 \%$ of calcium intake (Tab. 2 and 3). According to Alasalvar et al. (2009), among the minerals in Turkish hazelnut varieties, potassium was the most

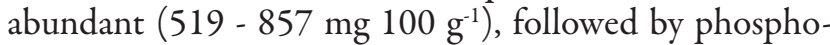

\begin{tabular}{cccccc}
\hline $\begin{array}{c}\text { Mineral composition } \\
(\mathrm{mg} / 100 \mathrm{~g})\end{array}$ & 'Cozia' & 'Romavel' & 'Valcea 22' & 'Roverd' & 'Red Lambert' \\
\cline { 2 - 6 } & $0.97 \pm 0.11^{*}$ & $0.36 \pm 0.03$ & $0.85 \pm 0.05$ & $0.52 \pm 0.03$ & $0.67 \pm 0.07$ \\
\hline Sodium, $\mathrm{Na}$ & $629.75 \pm 59.5$ & $592.38 \pm 3.05$ & $639.13 \pm 1.07$ & $633.86 \pm 3.58$ & $591.75 \pm 5.97$ \\
Potassium, $\mathrm{K}$ & $108.42 \pm 7.99$ & $72.07 \pm 2.61$ & $107.74 \pm 1.85$ & $130.92 \pm 1.47$ & $104.90 \pm 2.77$ \\
Calcium, $\mathrm{Ca}$ & $280.74 \pm 26.71$ & $205.02 \pm 4.28$ & $265.46 \pm 1.19$ & $335.54 \pm 1.05$ & $314.93 \pm 7.85$ \\
Magnesium, $\mathrm{Mg}$ & $7.82 \pm 0.56$ & $5.30 \pm 0.15$ & $7.98 \pm 0.06$ & $7.85 \pm 0.05$ & $8.77 \pm 0.19$ \\
Iron, $\mathrm{Fe}$ & $8.77 \pm 0.54$ & $9.96 \pm 0.03$ & $9.95 \pm 0.06$ & $19.07 \pm 0.14$ & $15.87 \pm 0.78$ \\
Manganese, $\mathrm{Mn}$ & $2.05 \pm 0.11$ & $1.62 \pm 0.03$ & $1.98 \pm 0.04$ & $3.07 \pm 0.06$ & $2.69 \pm 0.27$ \\
Copper, $\mathrm{Cu}$ & $0.35 \pm 0.02$ & $0.29 \pm 0.02$ & $0.31 \pm 0.01$ & $0.30 \pm 0.04$ & $0.23 \pm 0.02$ \\
Aluminium, $\mathrm{Al}$ & $0.68 \pm 0.06$ & $0.12 \pm 0.031$ & $0.84 \pm 0.03$ & $0.81 \pm 0.07$ & $0.69 \pm 0.05$ \\
Chromium, $\mathrm{Cr}$ & $2.84 \pm 0.26$ & $1.82 \pm 0.02$ & $2.38 \pm 0.03$ & $2.53 \pm 0.09$ & $2.53 \pm 0.04$ \\
Zinc, $\mathrm{Zn}$ & $1.35 \pm 0.12$ & $1.12 \pm 0.03$ & $0.88 \pm 0.03$ & $1.60 \pm 0.03$ & $1.19 \pm 0.06$ \\
Strontium, $\mathrm{Sr}$ & $1.34 \pm 0.13$ & $1.38 \pm 0.08$ & $1.77 \pm 0.05$ & $3.03 \pm 0.04$ & $1.67 \pm 0.08$ \\
Rubidium, $\mathrm{Rb}$ & $374.76 \pm 13.29$ & $300.67 \pm 2.90$ & $360.74 \pm 1.44$ & $455.06 \pm 1.38$ & $437.45 \pm 8.29$ \\
\hline Phosphorus, $\mathrm{P}$ & & &
\end{tabular}

${ }^{\mathrm{a}}$ Data are expressed as means $\pm \mathrm{SD}(\mathrm{n}=3)$. Means \pm SD followed by different lowercases indicate significant difference among cultivars $v s$. mean $\left({ }^{*} p<0.05\right)$

Tab. 3. Descriptive statistics (summary) for mineral elements ( $\mathrm{mg} / 100 \mathrm{~g}$ )

\begin{tabular}{ccccc}
\hline Mineral composition & Minimum & Maximum & $\begin{array}{c}\text { Mean } \\
(\mathrm{mg} / 100 \mathrm{~g})\end{array}$ & Standard Deviation \\
\hline Sodium, $\mathrm{Na}$ & 0.36 & 0.97 & 0.67 & 0.24 \\
\hline Potassium K & 591.75 & 639.13 & 617.34 & 23.34 \\
\hline Calcium Ca & 72.07 & 130.92 & 104.81 & 21.06 \\
\hline Magnesium $\mathrm{Mg}$ & 205.02 & 335.54 & 280.33 & 50.34 \\
\hline Phosphorus, P & 300.67 & 455.06 & 385.73 & 62.17 \\
\hline Iron, Fe & 5.30 & 8.77 & 7.53 & 1.31 \\
\hline Manganese, $\mathrm{Mn}$ & 8.77 & 19.07 & 12.72 & 4.50 \\
\hline Zinc, $\mathrm{Zn}$ & 1.82 & 2.84 & 2.42 & 0.37 \\
\hline Aluminium, Al & 0.23 & 0.35 & 0.29 & 0.04 \\
\hline Chromium, Cr & 0.12 & 0.84 & 0.62 & 0.29 \\
\hline Copper, Cu & 1.62 & 3.07 & 2.28 & 0.58 \\
\hline Rubidium, $\mathrm{Rb}$ & 1.34 & 3.03 & 1.83 & 0.69 \\
\hline Strontium, $\mathrm{Sr}$ & 0.88 & 1.60 & 1.22 & 0.26 \\
\hline
\end{tabular}


Tab. 4. Recommended dietary allowances (RDA) or adequate intake (AI) level of a nutrient*

\begin{tabular}{|c|c|c|c|}
\hline \multirow{2}{*}{ Nutrient } & \multicolumn{2}{|c|}{ Recommended Dietary Allowances } & \multirow{2}{*}{$\begin{array}{l}\text { Average content in cultivars studied } \\
(\mathrm{mg} / 100 \mathrm{~g})\end{array}$} \\
\hline & Unit & $\mathrm{RDA} / \mathrm{AI}$ & \\
\hline Calcium, $\mathrm{Ca}$ & $\mathrm{mg}$ & 1000 & 105.75 \\
\hline Iron, $\mathrm{Fe}$ & $\mathrm{mg}$ & 8 & 7.47 \\
\hline Magnesium, Mg & $\mathrm{mg}$ & 400 & 278.82 \\
\hline Phosphorus, $\mathrm{P}$ & $\mathrm{mg}$ & 700 & 386.22 \\
\hline Potassium, $\mathrm{K}$ & $\mathrm{mg}$ & 4700 & 612.40 \\
\hline Sodium, $\mathrm{Na}$ & $\mathrm{mg}$ & 1500 & 0.64 \\
\hline Zinc, $\mathrm{Zn}$ & $\mathrm{mg}$ & 11 & 2.35 \\
\hline Copper, $\mathrm{Cu}$ & $\mu \mathrm{g}$ & 900 & 2.26 \\
\hline Manganese, Mn & $\mathrm{mg}$ & 2.3 & 12.66 \\
\hline Selenium, Se & $\mu \mathrm{g}$ & 55 & undetermined \\
\hline Chromium, $\mathrm{Cr}$ & $\mu \mathrm{g}$ & 35 & 0.59 \\
\hline
\end{tabular}

*Source: http://en.wikipedia.org/wiki/Dietary_Reference_Intake\#Vitamins_and_minerals

rus (256 - $\left.314 \mathrm{mg} 100 \mathrm{~g}^{-1}\right)$, calcium (161 - $264 \mathrm{mg} 100$ $\left.\mathrm{g}^{-1}\right)$, and magnesium $\left(34.9-152 \mathrm{mg} 100 \mathrm{~g}^{-1}\right)$. Manganese is needed for bone development, healthy nerves, metabolism, a healthy immune system and regulating the blood sugar. Manganese content varied between $8.77 \mathrm{mg} 100$

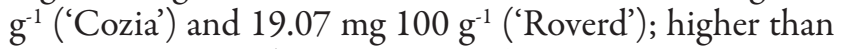

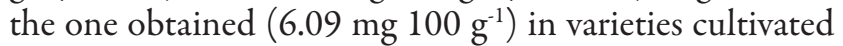
in Turkey (Açkurt et al., 1999). The recommended intake for adult is $2.3 \mathrm{mg}$ daily. According to the present study results, the five hazelnut cultivars have high $\mathrm{Mn}$ potential and may supply all of the human daily needs.

Iron content, in hazelnut cultivars here studied, was higher than the one found in Turkish hazelnut cultivars (Açkurt et al., 1999; Koksal et al., 2006; Özkutlu et al., 2011). Iron concentration in the present study was found

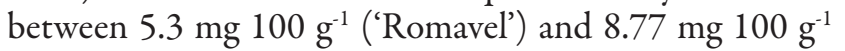
('Red Lambert'); the average iron content was $7.53 \mathrm{mg}$ $100 \mathrm{~g}^{-1}$. The results showed that hazelnut can be served as an excellent source of Fe. Consumption of $100 \mathrm{~g}$ hazelnut supplies $94 \%$ of iron intake (Tab. 2 and 3).

Copper, zinc, rubidium and strontium have recorded lower values in all cultivars studied (between $1-3.07 \mathrm{mg}$ $\left.100 \mathrm{~g}^{-1}\right)$; the rest of elements ( $\mathrm{Na}, \mathrm{Al}, \mathrm{Cr}$ ) were found in lower amounts, less than $1 \mathrm{mg} 100 \mathrm{~g}^{-1}$. Zinc and copper are two trace minerals, essential for important biochemical functions and necessary for maintaining health throughout life (Ma and Betts, 2000). The average copper level in cultivars is $2.28 \mathrm{mg} 100 \mathrm{~g} \mathrm{~g}^{-1}$. It was observed the highest amount of $\mathrm{Cu}$ in 'Roverd' (3.07 mg $100 \mathrm{~g}^{-1}$ ), while 'Romavel' cultivar hazelnuts had the lowest $\left(1.62 \mathrm{mg} 100 \mathrm{~g}^{-1}\right)$. Hazelnut varieties of $100 \mathrm{~g}$ amount can be a source of $\mathrm{Cu}$ to supply $100 \%$ of $\mathrm{Cu}$ daily human intake $(900 \mu \mathrm{g})$.

Zinc is an essential mineral that is naturally present in some foods, added to others, and is available as a dietary supplement. Zinc is involved in numerous aspects of cellular metabolism. It is required for the catalytic activity of approximately 100 enzymes (Sandstead, 1994). The results of this study showed that hazelnut can be important for completing the deficiency of $\mathrm{Zn}$ in daily intake about $22 \%$ levels. The highest $\mathrm{Zn}$ element concentrations of hazelnut were found in the 'Cozia' cultivar $\left(2.84 \mathrm{mg} 100 \mathrm{~g}^{-1}\right)$ while the lowest was found in 'Romavel' cultivar $(1.82 \mathrm{mg} 100$ $\left.\mathrm{g}^{-1}\right)$; the average content is $2.42 \mathrm{mg} 100 \mathrm{~g}^{-1}$.

Chromium is an essential mineral. Chromium works with insulin to improve the transportation of glucose out of the blood and into the cell (Cefalu and $\mathrm{Hu}, 2004$ ). According to the present study results, an average $5.6 \%$ of dietary $\mathrm{Cr}$ intake can be easily obtained from consumption of hazelnut at $100 \mathrm{~g} /$ day. The concentrations of $\mathrm{Cr}$ ranged from 0.12 to $0.84 \mathrm{mg} 100 \mathrm{~g}^{-1}$ for the analyzed hazelnut varieties. Özkutlu et al. (2011) reported the content of $\mathrm{Cr}$ that varied between 0.02 to $0.05 \mathrm{mg} \mathrm{kg}^{-1}$.

The health benefits of sodium play a pivotal role in enzyme operation and muscle contraction. It is important for osmo-regulation and fluid maintenance of the human body. Other health benefits of sodium include heart performance, nervous system and glucose absorption (Murphy and Eisner, 2009). Sodium concentration in this study was found to be between 0.36 ('Romavel') and $0.97 \mathrm{mg}$ $100 \mathrm{~g}^{-1}$ ('Cozia'). The highest sodium content was found in Turkish hazelnut cultivars (the amount of Fe is found to be

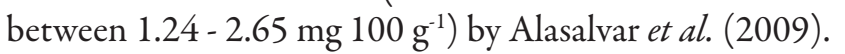

\section{Conclusions}

The data obtained in this study do confirm that hazelnuts are a rich source of a number of important microelements, and their mineral content within the $100 \mathrm{~g}$ hazelnut was greater than human daily consumption for this required level. The results showed that an important part of daily K, P, Mg, Ca, Mn, Fe, Zn, Cu, Rb, Sr, Na, Cr, and $\mathrm{Al}$ requirement for human nutrition can be supplied by the daily consumption of $100 \mathrm{~g}$ hazelnut. According to the daily micro-element requirements and results of the present study, the amount of $100 \mathrm{~g}$ hazelnut has supplied about $13 \%$ for $\mathrm{K}, 55 \%$ for $\mathrm{P}, 70 \%$ for $\mathrm{Mg}, 10 \%$ for $\mathrm{Ca}$, $94 \%$ for $\mathrm{Fe}, 22 \%$ for $\mathrm{Zn}$ and $5.6 \%$ for $\mathrm{Cr}$ of the RDA. For $\mathrm{Mn}$ and $\mathrm{Cu}$, the levels of $100 \mathrm{~g}$ hazelnuts are higher than the respective daily requirements. 
254

\section{Acknowledgments}

The authors are grateful to the team of researchers from University of Craiova, the Fruit Growing Research \& Extension Station in Valcea, for biological material.

\section{References}

Açkurt F, Özdemir M, Biringen G, Löker M (1999). Effects of geographical origin and variety on vitamin and mineral composition of hazelnut (Corylus avellana L.) varieties cultivated in Turkey. Food Chem 65:309-313.

Alasalvar C, Shahidi F, Liyanapathirana CM, Ohshima T (2003). Turkish Tombul hazelnut (Corylus avellana L.). 1. Compositional characteristics. J Agric Food Chem 51:37903796.

Alasalvar C, Amaral JS, Satir G, Shahidi F (2009). Lipid characteristics and essential minerals of native Turkish hazelnut varieties (Corylus avellana L.). Food Chem 113:919-925.

Alphan E, Pala M, Açkurt F, Yilmaz T (1997). Nutritional composition of hazelnuts and its effects on glucose and lipid metabolism. Acta Horticulturae 445:305-310.

Amaral JS, Casal S, Alves MR, Seabra RM, Oliveira BBP (2006). Tocopherol and tocotrienol content of hazelnut cultivars grown in Portugal. J Agric Food Chem 54:1329-1336.

AOAC (2000). Official methods of analysis of AOAC international (17 ${ }^{\text {th }}$ ed.). Gaithersburg, MD: AOAC International.

Botu I, Turcu E, Preda S, Botu M, Achim G (2005). 25 years of achievements and perspectives in hazelnut breeding in Romania. Acta Horticulturae 686:91-94.

Cefalu WT, Hu FB (2004). Role of chromium in human health and in diabetes. Diabetes Care 27:2741-2751.

Contini M, Baccelloni S, Massantini R, Anelli G (2008). Extraction of natural antioxidants from hazelnut (Corylus avellana L.) shell and skin wastes by long maceration at room temperature. Food Chem 110:659-669.

Cosmulescu S, Botu M, Trandafir I (2010). Mineral composition and physical characteristics of walnut (Juglans regia L.) cultivars originating in Romania. Selçuk J Agr Food Sci 24(4):33-37.

Cristofori V, Ferramondo S, Bertazza G, Bignami C (2008). Nut and kernel traits and chemical composition of hazelnut (Corylus avellana L.) cultivars. J Sci Food Agr 88:10911098.

Demigné C, Sabboh H, Rémésy C, Meneton P (2004). Protective effects of high dietary potassium: nutritional and metabolic aspects. J Nutr 134:2903-2906.

Demirbas A (2007). Phenolics from hazelnut kernels by supercritical methanol extraction. Energy sources Part A 29(9):791-797.

Dundar MS, Bahçivanc E, Muslu C (2002). Influence of variety and geographical region on mineral contents of hazelnut (Corylus avellana L.) varieties. Acta Chim Slov 49:537-544.

Ferreira JJ, Garcia-González C, Tous J, Rovira M (2010). Genetic diversity revealed by morphological traits and ISSR markers in hazelnut germplasm from northern Spain. Plant Breeding 129:435-441.

Gunes NT, Köksal Aİ, Artik N, Poyrazoğlu E (2010). Biochemical content of hazelnut (Corylus avellana L.) cultivars from West Black Sea Region of Turkey. Eu J Hortic Sci 75(2):7784.

Koksal AI, Artik N, Simsek A, Gunes N (2006). Nutrient composition of hazelnut (Corylus avellana L.) varieties cultivated in Turkey. Food Chem 99:509-515.

Ma J, Betts NM (2000). Zinc and copper intakes and their major food sources for older adults in the 1994-96 continuing survey of food intakes by individuals (CSFII). J Nutr 130:2838-2843.

Murphy E, Eisner DA (2009). Regulation of intracellular and mitochondrial sodium in health and disease. Circ Res 104:292-303.

Oliveira I, Sousa A, Morais J, Ferreira ICFR, Bento A, Estevinho L, Pereira JÁ (2008). Chemical composition, and antioxidant and antimicrobial activities of three hazelnut (Corylus avellana L.) cultivars. Food Chem Toxicol 46:1801-1807.

Ozdemir F, Akinci I (2004). Physical and nutritional properties of four major commercial Turkish hazelnut varieties. J Food Eng 63:341-347.

Özkutlu F, Doğru YZ, Özenç N, Yazici G, Turan M, Akçay F (2011). The importance of Turkish hazelnut trace and heavy metal contents for human nutrition. J Soil Sci Environ Manage 2:25-33.

Rovira M, Ferreira JJ, Tous J, Ciordia M (2005). Hazelnut diversity in Asturias (Northern Spain). Acta Horticulturae 686:41-46.

Sandstead HH (1994). Understanding zinc: recent observations and interpretations. J Lab Clin Med 124:322-327.

Schmitzer V, Slatnar A, Veberic R, Stampar F, Solar A (2011). Roasting affects phenolic composition and antioxidative activity of hazelnuts (Corylus avellana L.). J Food Sci 76:S14S19.

Seyhan F, Ozay G, Saklar S, Ertaş E, Satir G, Alasalvar C (2007). Chemical changes of three native Turkish hazelnut varieties (Corylus avellana L.) during fruit development. Food Chem 105:590-596.

Silva AP, Santos A, Cavalheiro J, Ribeiro C, Santos F, Gonçalves B (2007). Fruit chemical composition of hazelnut cultivars grown in Portugal. J Appl Hortic 9(2):157-161.

Simsek A, Aykut O (2007). Evaluation of the microelement profile of Turkish hazelnut (Corylus avellana L.) varieties for human nutrition and health. Int J Food Sci Nutr 58:677-688.

Solar A, Stampar F (2011). Characterization of selected hazelnut cultivars: phenology, growing and yielding capacity, market quality and nutraceutical value. J Sci Food Agr 91:1205-1212.

Xu Y, Hanna MA (2011). Nutritional and anti-nutritional compositions of defatted Nebraska hybrid hazelnut meal. Int J Food Sci Technol 46:2022-2029. 